\title{
Control of Corruption, Regulatory Quality, Political Stability and Environmental Sustainability: A Cross-National Analysis
}

\author{
Sofik Handoyo \\ Faculty of Economics and Business \\ Universitas Padjadjaran \\ Fury Khristianty Fitriyah \\ Faculty of Economics and Business \\ Universitas Padjadjaran
}

\begin{abstract}
The study aims to reveal the correlation between governance attributes of the government and national environmental sustainability. The governance attributes of government in this study refer to the index of control of corruption, regulatory quality, and political stability. Meanwhile, national environmental sustainability refers to the index of national environmental performance. The period of investigation is the year of 2014 and involves 177 countries. Person correlation analysis was applied in this study to identify the degree of correlation between independent variables (control of corruption, regulatory quality, and political stability) dependent variable (environmental sustainability). Independent variables were measured using the World Governance Index (WGI) published by the World Bank. Environmental Performance Index (EPI) issued by The Yale Center for Environmental Law \& Policy (YCELP) was proxied for measuring environmental sustainability. The results indicate that the state's control of corruption, the national regulatory quality, and national political stability are positively associated with national environmental sustainability. The correlation coefficients are $0.230(\mathrm{p}<0.01), 0.193(\mathrm{p}<0.01)$, and $0.167(\mathrm{p}<0.01)$, respectively. Even though there is a positive correlation between public governance attributes and national environmental sustainability, however, the degree of correlation is weak. It implies that national governance is not a powerful instrument to predict national environmental sustainability.
\end{abstract}

Keywords: Control of corruption; Regulatory quality; Political stability; Environmental sustainability,

\section{Introduction}

In recent decades it has become evident that environmental degradation is a growing problem with implications for poverty reduction as well as for the health of ecosystems (Sundström, 2013). Environmental issues are being an intense discussion among nations and corporations. They have the same concern, saving the earth from the negative impact of industrialization and nature exploitation. In order to support the population's life in the future, the environment must be prevented from further destruction. Therefore, economic development activities should 
also consider environmental sustainability. Environmental sustainability is one of the main points of Millennium Development Goals (MDGs) initiated by United of Nations on Millennium Summit occasion in 2000. The milestone of the environmental protection movement by global communities was started in 1992, resulting Kyoto Protocol, governing about greenhouse gases reduction. Following Kyoto occasion, in the same year, Earth Summit in Rio de Janerio released agenda 21 of sustainability development. Those events initiated by United nations implies that environmental issues are crucial for international communities and challenges to be faced collectively (Scruggs, 1999).

The thinking of environment sustainability is driven by a general understanding of global communities that the earth is no longer a friendly place for living. Sustainable development provides a framework for humans to live and prosper in harmony with nature rather than living, as we have done for centuries, at nature ${ }^{e c} \mathrm{~s}$ expense (Dernbach and Mintz, 2011). Many economic activities, especially industrialization and natural resources exploitation, are believed causing deterioration of environmental quality. Global warming, the ozone layer's depletion, natural disaster, climate changes are the harmful impact of irresponsible economic activities (Fiorino, 2010). Industrialization and natural resources exploitation in one side is benefiting the state, the other side, it will harm environmental if it is not managed carefully. In this case, national involvement as the regulator is very pivotal in achieving environmental sustainability. Environmentally friendly industrialization is effectively practiced if the state has a full commitment to doing it. However, it is not an easy duty to be conducted by the state.
Many factors are contributing to the achievement of environmental sustainability goals. However, internal factors such as the ability of the state to combat corruption, the regulatory quality, and domestic political stability are believed playing a significant role in determining successful environmental sustainability goals.

Corruption is the typical negative behavior of the national official associated with the failure to achieve sustainable development. Bribery from the private sector to the official government is a classic example of corruption among state officials. Plenty of anecdotal evidence suggests that corruption harms the environment; bribery assists the poaching of rhinos in protected savannas and enables the illegal logging of timber in tropical forest reserves (Sundström, 2013). Issuing business permits that are endangering population and environment, neglecting fines for a business practice that are ignoring the environmental law and regulations, giving easy sanctions and punishment for any actions against the environmental law and regulations are common practice that is believed involving bribery. Impact of bribery is very significantly related to sustainable development. Therefore, the ability of the state to control corruption practice will determine whether sustainable development can be achieved or not. Even though there are many assumed causeeffect relationships between corruption and environmental sustainability, however, there are still few empirical analyses (Morse, 2006). Therefore, further quantitative research about the influence of corruption and environmental sustainability needs to be conducted. 
Sustainability development is a vision of global communities to be achieved. However, to achieve sustainable development, infrastructure such as sufficient regulatory should be in place. Regulation, one of the three fundamental levers of state power (together with fiscal and monetary policy), is of critical importance in shaping the welfare of economies and society (OECD, 2010). The regulatory should have good quality and enforcement power that make business practice aware of environmental issues. Regulatory quality is reflected by its effectiveness to achieve the purposes of regulation itself. In this case, the intended purpose is environmental protection. Public awareness of environmental issues in proposing good quality of regulation will be a crucial factor in achieving environmental sustainability. By having a good quality of environmental law and regulation, the law and regulation will have the power to force stakeholder from any actions that lead to environmental destruction.

Ability to achieve environmental sustainability is typically also influenced by domestic factors. One of the crucial factors determines the achievement of environmental sustainability is domestic political stability. Domestic political stability will determine the national priority, such as budget allocation and management of the government. Environmental issues may not get sufficient attention if the domestic political situation is unstable. The states may more focus on activities to stabilize the domestic politic situation than that of taking care of environmental issues. Neglecting environmental issues are found in many countries involved in an unstable domestic politic condition such as civil war, premature changing of National's leader and military coupe. The bottom line of the unstable domestic politic condition, it will take consequences of national priority in conducting national development, in this case, environmental development

\section{Literature Review and Hypothesis Development}

\section{Control of corruption dan Environmental Sustainability}

World Bank defines corruption as the abuse of public power for private gain. Corruption, in its various forms, is generally believed to be an obstacle to economic development (Aidt, 2009). Corruption undermines democracy and reduces economic growth, and it diverts public funds to serve the private interests of some public officials (Winbourne, 2002). Corruption "has distorted development priorities, led to massive human and financial capital flight, and undermined social and political stability (Doig and McIvor (1999). Robust evidence that corruption, as opposed to general government inefficiency, has a sizable negative effect on growth in real GDP per capita (Aidt, 2009). Rampant corruption can put an economy on an unsustainable path along which its capital base is being eroded.

The theoretical accounts for why corruption harms the environment are quite vague, mainly consisting of two strands of explanations. One is focused on the content of rules, arguing that corruption affects the substantial stringency of environmental regulations, as bribery shapes policy in corrupt societies. Another explanation instead focuses on that corruption hampers law enforcement, thus allowing emitters to evade the responsibility of pollution or encouraging the overexploitation of resources (Sundström, 2013). 
Corruption has not only been linked to social and economic development but also environmental sustainability (Lopez and Mitra, 2000; Damania et al. 2003, Welsch 2004). While corruption is not environmentally destructive in a general sense, poor governance results in lousy policy formulation, management, and enforcement, and this can become apparent through problems with environmental sustainability (Damania et al. 2003). In the environmental and natural resources sector, public sector corruption serves the private interests of bureaucrats and criminals by taking away from citizens their rights to the clean and complete environment, misallocating environmental resources, and diverting funds from conservation and preservation (Winbourne, 2002).

Corruption in the environmental and natural resources sectors may occur across many transactions, starting from bribery and cronyism on the level of developing national policy and embezzlement in implementing environmental programs to bribery in issuing permits and licenses and collecting "rents" while enforcing environmental regulations (Winbourne, 2002). The environment can be affected by corruption in other sectors, for example, in agriculture, privatization, public procurement, customs, the judiciary, and others. Thus, privatization conducted through corrupt procedures may allow new owners to use privatized land or facilities in an environmentally damaging manner; or regulations and procedures established in customs may open opportunities for trafficking in wildlife (Winbourne, 2002).

A body of empirical research has demonstrated a pattern where national levels of corruption affect the loss of biodiversity, the success of conservation, and correlate negatively with aggregate measures of sustainability (Sundström, 2013). Meyer et al. (2003) who studied institutional factors and deforestation, found that there is a strong correlation between corruption and deforestation in 117 countries. Fredriksson and Svensson (2003) propose a theoretical model that environmental quality is negatively influenced by corruption and political stability. It implies that the more corruption, the less environmental sustainability will be. The theoretical model of Fredriksson and Svensson (2003) is supported by the empirical research of Welsch (2004). The research found that the quality of the environment in developing countries is negatively correlated with corruption. Kelleher (2009) suggests that countries with low national income could improve their environmental performance by decreasing corruption. Based on the literature review mentioned above, the hypothesis is proposed as follows:

Hypothesis 1: National control of corruption is positively significant associated with the national environmental sustainability

\section{Regulatory Quality and Environmental Sustainability}

Regulation is the laws and norms adopted by the state, followed by the consequence of fined or punishment for those who break it (Coglinanese, 2012). Regulation is an instrument for the state to achieve its goals; one of them is namely creating environmental sustainability. Regulatory quality can be measured by the ability of the regulation in achieving its goals. Associated with environmental sustainability, the regulatory quality will determine the state's environmental performance (Esty and Porter, 2001). Scruggs (1999) suggest that tight regulatory give an incentive for business and the state for flexible cooperation in achieving better environmental performance. OCED (2008) mentions three indicators to measure regulatory quality; 1) transparency, 2) nondiscriminant and efficiency. Regulatory that has good and beyond quality help the 
state to achieve goals of public policy such as safety, health, environmental sustainability (Treasury Board of Canada Secretariat, 2011).

Rules are essential for economic growth, social welfare, and environmental protection. By improving, regulatory management and regulatory reform are among the best ways that governments can promote economic development, investment, and trade (OECD, 2008). World Bank defines. Regulatory quality is perceptions of the ability of the government to formulate and implement sound policies and regulations that permit and promote private sector development. The quality of a country's regulatory system depends to a great extent on how regulations are conceived and made. Governments are concerned to ensure that their regulations operate efficiently to boost economic growth, social welfare, and environmental standards (OECD, 2008) Effective regulation can provide strong support for meeting these challenges. Ineffective regulation, conversely, will slow recovery, inhibit growth, undermine efforts to address complex issues such as climate change and reinforce citizens' skepticism of government (OECD, 2010).

In order to achieve environmental sustainability, we also need to recognize regulatory quality. Environmental law is a key to achieving sustainability; it provides essential tools and institutions for governing sustainably (Dernbach and Mintz, 2011). If we are to make significant progress toward a sustainable society, much less achieve sustainability, we will need to develop and implement laws and legal institutions that do not now exist, or that exist in a much different form ( Dernbach and Mintz, 2011). Based on the literature cited above, the hypothesis can be proposed as follows:
Hypothesis 2: National Regulatory quality is positively significant associated with national environmental sustainability.

\section{Political Stability and Environmental}

\section{Sustainability}

Political stability concept broadness is based on government stability and stability of the political regime on one side, and stability of internal legal and external stability on another side (Akongdit, 2013). In times of crisis, the role of the political economy is crucial in redefining the policies and objectives that must assure the desired economic outcomes (Radu, 2015). A steady political leadership advertently leads to sustained economic growth. Political instability is regarded by economists as a serious malaise harmful to economic performance. It may also lead to a more frequent switch of policies, creating volatility and thus, negatively affecting macroeconomic performance ( Aisen and Vega, 2011). Alesina and Perotti (1996) argue that socio-political instability generates an uncertain politico-economic environment. Political instability shortens the horizons of governments, disrupting long-term economic policies conducive to better economic performance ( Aisen and Veiga, 2011). Political instability, human rights violations, and corruption are among the main challenges to sustainable development in the country (Khadka, 2011)

The awareness of the strong links between socio-political and ecological systems has increased over time (Lubchenco, 1998). Environmental degradation is often a pivotal contributor to sociopolitical instability, and democracybuilding is not likely in the face of poor stewardship of the environment (Lubchenco, 1998). Understanding long- 
term trends in socio-political development can help in catalyzing a transition to sustainability (Kates and Parris, 2003). Countries with sustainable economies will exhibit less instability over time than countries with unsustainable economies (Goodland, 1995). Good governance and socio-political stability are precursors to environmental protection and sustainability (Rees, 2006). Lubchenco (1998) speculated that the future trajectory of the earth would likely be characterized by rapid change, and greater uncertainty about the dynamics of ecological, as well as social and political systems

Didia (1997) found a negative correlation between the level of democracy and the rate of deforestation in a study of developing nations. Conca and Wallace (2009), citing a significant body of literature, build a case indicating that poor environmental stewardship precludes socio-political stability. They contend that poor environmental stewardship will result in increased vulnerability to natural disasters, as well as a substantial negative impact on the institutions necessary for socio-political stability (Conca and Wallace, 2009). In particular, they argue that the quality of environmental stewardship is at the threshold of whether a developing country travels down a peaceful or violent path. Environmental quality is dominated by socio-political factors (Grafton and Knowles, 2004).

Barrett and Graddy (2000), in a study analyzing numerous pollution variables, found that environmental quality improves with advances in civil and political freedoms. High corruption and political instability would have a negative compounding effect on environmental regulations (Karunanithi et al., 2011). Impact of the environment caused by economic changes depends on the political institution and decision making (Kelleher et al. (2009). Fiorino (2010) argues that there is strong evidence that associates environmental degradation, politic legitimation, and political stability. Based on the literature review mentioned above, the hypothesis is proposed as follows:

Hypothesis 3: National Political Stability is positively significant associated with the national environmental sustainability

\section{Methodology}

The data of control of corruption, regulatory quality, and political stability was generated from World Governance Index (WGI). World Governance Index is an index to measure governance of the government worldwide conducted by the World Bank. Environmental Sustainability in this research was represented by the Environmental Performance Index (EPI). The Environmental Performance Index (EPI) ranks countries' performance on highpriority environmental issues in two areas: protection of human health and protection of ecosystems. Environmental Performance Index (EPI) is conducted and published by the Yale Center for Environmental Law \& Policy (YCELP).

The data is collected from open access data publication from the official website of the World Bank and YCELP. This research Involved 177 countries with the period of investigation is the year of 2014. There are only 177 countries of 193 population were chosen due to not all population has both the Environmental Performance Index and Governance Index. The reason for using the year of 2014 as a time of investigation is the latest data availability consideration. Normality of the data was tested with One-Sample Kolmogorov - Smirnov. Parametric statistical test, Pearson correlation analysis 
was adopted in this research to understand the relationship among variables. SPSS Statistical tool version 23 was deployed in helping the calculation the normality test and correlation test.

\section{Results}

\section{Data Normality Test}

Data normality test is required to make sure that a data set is well-modeled by a normal distribution. It is also required for a random variable underlying the data set to normally distributed. The analysis of the research is using Parametric Statistical test; therefore, a set data normally distributed is required. The results of data normality test using One-Sample Kolmogorov - Smirnov is presented in table 1 below:

Table 1. Normality Test

\begin{tabular}{lccc}
\hline \multicolumn{1}{c}{ Variables } & $\begin{array}{c}\text { One-Sample } \\
\text { Kolmogorov Smirnov }\end{array}$ & $\begin{array}{c}\text { Critical } \\
\text { Value }\end{array}$ & $\begin{array}{c}\text { The conclusion of } \\
\text { Data Distribution }\end{array}$ \\
\hline Control of Corruption & 0.132 & 0.05 & Normal \\
Political Stability & 0.063 & 0.05 & Normal \\
Regulatory Quality & 0.072 & 0.05 & Normal \\
\hline
\end{tabular}

A set of data is normally distributed if based on normality test; the outcome of the test statistic is higher than the critical value of 0.05 (Test Statistic > 0.05). Based on the normality test presented in Table 1, it indicates that all variables have a normality test statistic results higher than the critical value of 0.05 . Therefore, we can conclude that the data set of variable control of corruption, variable political stability, variable regulatory quality, and variable environmentally quality is normally distributed. Since the data is normally distributed, parametric statistical test using Pearson Correlation analysis test is allowed.

\section{Correlation Analysis}

Correlation is another way of assessing the relationship between variables. To be more precise, it measures the extent of correspondence between the ordering of two random variables. Correlation denotes the interdependency among the variables for correlating two phenomena. This research was developed to identify the relationships between two variables. Since the purpose of the research is investigating the relationship between two random variables, correlation statistical analysis test is believed as the right one. The results of the correlation analysis are presented in Table 2 below:

Table 2. Correlation Analysis Matrix

\begin{tabular}{lllll}
\hline & $\begin{array}{l}\text { Control of } \\
\text { Corruption }\end{array}$ & $\begin{array}{l}\text { Political } \\
\text { Stability }\end{array}$ & $\begin{array}{l}\text { Regulatory } \\
\text { Quality }\end{array}$ & $\begin{array}{l}\text { Environmental } \\
\text { Sustainability }\end{array}$ \\
\hline Control of Corruption & 1 & $0.757^{* *}$ & $0.859^{* *}$ & $0.230^{* *}$ \\
Political Stability & $0.757^{* *}$ & 1 & $0.666^{* *}$ & $0.167^{*}$ \\
$\begin{array}{l}\text { Regulatory Quality } \\
\text { Environmental }\end{array}$ & $0.859^{* *}$ & $0.666^{* *}$ & 1 & $0.193^{* *}$ \\
$\begin{array}{l}\text { Sustainability } \\
\text { ** p<0.01 level (1-tailed). }\end{array}$ & $0.230^{* *}$ & $0.167^{*}$ & $0.193^{* *}$ & 1 \\
$* . \mathrm{p}<0.05$ level (1-tailed). & & & & \\
\hline
\end{tabular}


In this research, the design of the correlation analysis is one way in term of the direction of correlation, which is a positive correlation direction. The argumentation of using one-way correlation analysis test is due to the robust literature supporting the direction of the relationship between two variables. Pearson Correlation Matrix in Table 2 indicates that variables control of corruption, political stability, and regulatory quality correlate with variable environmental sustainability. However, the degree of correlation is relatively weak $(<$ $0.25)$. The strong correlation $(>0.5)$ is happening between variable variables control of corruption, political stability, and regulatory quality. As in the literature mentions, control of corruption, political stability, and regulatory quality are

Table 3. Summary of Hypothesis Testing components of Governance of the Government.

\section{Hypothesis Testing}

In this research, there were three hypotheses propose. The first hypothesis, control of corruption is positively associated with environmental sustainability. The second hypothesis, regulatory quality, is positively associated with environmental sustainability. The third hypothesis, political stability, is positively associated with environmental sustainability. After conducting correlation analysis, as mentioned in the correlation analysis section, the summary of the hypothesis testing is presented as follows:

\begin{tabular}{lcc}
\hline Hypothesis & $\begin{array}{c}\text { Correlation } \\
\text { Coefficient }\end{array}$ & Conclusion \\
\hline $\begin{array}{l}\text { H1: Control of Corruption is positively associated } \\
\text { with Environmental sustainability }\end{array}$ & $0.230^{* *}$ & Significant \\
H2: Regulatory quality is positively associated with & $0.193^{* *}$ & Significant \\
$\begin{array}{l}\text { Environmental sustainability } \\
\text { H3: Political Stability is positively associated with } \\
\text { Environmental sustainability }\end{array}$ & $0.167 *$ & Significant \\
$* * \cdot p<0.01$ level (1-tailed). & & \\
$* . p<0.05$ level (1-tailed). & &
\end{tabular}

Based on information summarized in table 3, it concludes that all proposed hypotheses are supported. However, there is a note in this conclusion, and it is about the degree of correlation. As mentioned previously in the correlation analysis, the degree of correlation is relatively weak. It implies that variable control of corruption, regulatory quality, and political stability correlate statistically, but not convincing. However, from the perspective of the research, scientific investigation results are fully supporting the theoretical framework that control of corruption, regulatory quality, and political stability are determines environmental sustainability.

\section{Conclusion}

The research concludes that national control of corruption, regulatory quality, and political stability are associated with national environmental sustainability. Even though the degree of correlation is relatively weak, however, at least we have an opinion that public governance is associated with national environmental sustainability. Referring to the World Bank, 
governance of government will be determined by factors such as control of corruption, regulatory quality, and political stability. With this finding, it supports the theoretical framework that the application of good governance principles in the governmental institution will contribute to environmental sustainability.

In order for achieving environmental sustainability goals, the nation must commit to combat corruption practice. By eradicating corruption behavior among national officials, possibilities for inappropriate business practice that destructs and endanger the environment can be minimized. Regulatory quality determines the achievement of the goal of regulation itself. By having law and regulations that genuinely consider environmental protection and has the power to force obedience among stakeholder, the goals of environmental sustainability will be achieved. Domestic political stability enables the state to continue of national development program without any interferer. The state will have attention to develop the nation related environmental if the domestic political condition is stable.

For further research, an extension of the period of investigations is suggested. Longitudinal data panel with more countries involved is recommended. Furthermore, micro-level analysis of environmental sustainability such as health, air quality, water quality is the potential subject of the research to be conducted. By conducting more details investigation of environmental sustainability, we will get more specific information about an aspect of environmentally affected by control of corruption, regulatory quality, and political stability. The last, model analysis using regression analysis and also multivariate analysis is recommended.

\section{References}

Aidt, Toke S. 2009. "Corruption, Institutions and Economic Development," Oxford Review of Economic Policy 25: 271-291

Akongdit, Addis (2013), "Impact of Political Stability on Economic Development: Case of South Sudan," Author House, UK.

Alesina, A. and Perotti, R. (1996). "Income distribution, political instability, and investment." European Economic Review 40, 1203- 1228

Aisen, Ari and Veiga, Francisco Jose. 2011. How Does Political Instability Affect Economic Growth? IMF Working Paper.

Barrett, S., Graddy, K., 2000. Freedom, growth, and the environment. Environment and Development Economics 5, 433-456

Conca, K., Wallace, J., 2009. Environment and peacebuilding in war-torn societies: lessons from the UN Environment Programme's experience with postconflict assessment. Global Governance 15, 485-504

Coglinanese, Cary. 2012. Measuring Regulatory Performance: Evaluating The Impact of Regulation and Regulatory Policy. OECD Expert Paper No. 1, Augustus.

Doig, A., and S. McIvor. 1999. Corruption and its control in the developmental context: an analysis and selective review of the literature. Third World Quarterly 20(3):657-676. 
Didia, D.O., 1997. Democracy, political instability and tropical deforestation. Global Environmental Change 7, 63-76

Damania, R., P. G. Fredriksson, and J. A. List. 2003. Trade liberalization, corruption, and environmental policy formulation: theory and evidence. Journal of Environmental Economics and Management 46(3):490-512

Dernbach, John C. and Mintz., Joel A. 2011. Environmental Laws and Sustainability: An Introduction. Sustainability 2011, 3, 531-540.

Esty, Daniel C., dan Porter, Michael. 2001. Ranking national environmental regulation and performance: $\mathrm{A}$ leading indicators for future competitiveness.

Fiorino, Daniel J. 2010. Explaining National Environmental Performance: What Do We Know and What Should We Learn?. Center for Environmental Policy Department of Public Administration. and Policy. Working Paper November

Fredriksson, Per G. and Svensson, Jakob. 2003. Political instability, corruption and policy formation: the case of environmental policy. Journal of Public Economics

Goodland, R., 1995. The concept of environmental sustainability. Annual Review of Ecology and Systematics 26, 1-24.

Grafton, R.Q., Knowles, S., 2004. Social capital and national environmental performance: a cross-sectional analysis. Journal of Environment and Development 13, 336-370
Khadka, Sarba Raj. 2011. Biodiversity Conservation in Nepal: Policies and Ground Realities, (Saarbrücken, Germany: Lambart Academic Publishing

Karunanithi, Arunprakash T, Ahjond S. Garmestani, Tarsha Eason, Heriberto Cabezas. 2011. The characterization of socio-political instability, development and sustainability with Fisher information. U.S. Environmental Protection Agency Papers. Paper 204

Kates, R.W., Parris, T.M., 2003. Long term trends and a sustainability transition. Proceedings of the National Academy of Sciences of the United States of America 100, 8062-8067.

Kelleher, David., Geum-Soo Kim \& Young-Jae Chang. Do Differences in Political Institutions Explain Differences in Environmental Policy Performance across Countries?. Paper presented at the APPAM-KDI International Conference on Environmental Policy and Teaching Methods (Seoul, June 11-13, 2009)

Lopez, R., and S. Mitra. 2000. Corruption, pollution, and the Kuznets environment curve. Journal of Environmental Economics and Management 40(2):137-150

Lubchenco, J., 1998. Entering the century of the environment: a new social contract for science. Science 279 , 491-497

Morse, S. 2006. Is corruption bad for environmental sustainability? a cross-national analysis. Ecology and Society11(1): 22 
OECD, 2010. Regulatory Policy and the Road to Sustainable Growth. OECD Report

OECD, 2008. Measuring Regulatory Quality. OECD observer, April 2008.

Rees, W.E., 2006. Globalization, trade and migration: undermining sustainability. Ecological Economics 59, 220-225

Radu, Mădălina. 2015. Political stability - a condition for sustainable growth in Romania? Procedia Economics and Finance 30 (2015)

Scruggs, Lyle A. Institutions and Environmental Performance in Seventeen Western Democracies. British Journal of Political Science / Volume 29 / Issue 01 / January 1999
Sundström, Aksel. 2013. Corruption in the commons: Why bribery hampers enforcement of environmental regulations in South African fisheries. International Journal of the Commons Vol. 7, no 2 August 2013, pp. 454-472

Treasury Board of Canada Secretariat. 2011. Indicators of regulation and regulatory policy performance Canada's vision Madrid Workshop, Sept. 26

Welsch, H. 2004. Corruption, growth, and the environment: a cross-country analysis. Environment and Development Economics 9:663693

Winbourne, Svetlana. 2002. Corruption and the environment. USAID Research Report. 